\title{
Prediction of total quarter milk somatic cell counts based on foremilk sampling
}

\author{
Olga Wellnitz ${ }^{1}$, Marcus G Doherr², Marta Woloszyn ${ }^{3}$ and Rupert M Bruckmaier ${ }^{1 *}$ \\ ${ }^{1}$ Veterinary Physiology, Vetsuisse Faculty, University of Bern, Bern, Switzerland \\ ${ }^{2}$ Experimental Clinical Research, Vetsuisse Faculty, University of Bern, Bern, Switzerland \\ ${ }^{3}$ DeLaval International AB, Tumba, Sweden
}

Received 12 August 2008; accepted for publication 23 January 2009; first published online 18 May 2009

\begin{abstract}
Determination of somatic cell count (SCC) is used worldwide in dairy practice to describe the hygienic status of the milk and the udder health of cows. When SCC is tested on a quarter level to detect single quarters with high SCC levels of cows for practical reasons, mostly foremilk samples after prestimulation (i.e. cleaning of the udder) are used. However, SCC is usually different in different milk fractions. Therefore, the goal of this study was the investigation of the use of foremilk samples for the estimation of total quarter SCC. A total of 378 milkings in 19 dairy cows were performed with a special milking device to drain quarter milk separately. Foremilk samples were taken after udder stimulation and before cluster attachment. SCC was measured in foremilk samples and in total quarter milk. Total quarter milk SCC could not be predicted precisely from foremilk SCC measurements. At relatively high foremilk SCC levels $\left(>300 \times 10^{3}\right.$ cells $\left./ \mathrm{ml}\right)$ foremilk SCC were higher than total quarter milk. At around (50-300) $\times$ $10^{3} \mathrm{cell} \mathrm{s} / \mathrm{ml}$ foremilk and total quarter SCC did not differ considerably. Most interestingly, if foremilk SCC was lower than $50 \times 10^{3} \mathrm{cell} / \mathrm{s} / \mathrm{ml}$ the total quarter SCC was higher than foremilk SCC. In addition, individual cows showed dramatic variations in foremilk SCC that were not very well related to total quarter milk SCC. In conclusion, foremilk samples are useful to detect high quarter milk SCC to recognize possibly infected quarters, only if precise cell counts are not required. However, foremilk samples can be deceptive if very low cell numbers are to be detected.
\end{abstract}

Keywords: Udder health, somatic cell count, foremilk, quarter milk.

Somatic cell count (SCC) is the most widespread udderhealth and milk hygienic parameter in dairy practice because an infection of the mammary gland is the major factor that increases the SCC. Infections reduce both the quality and the yield of milk, and the SCC of individual quarters can affect the total milk SCC of the cow and, consequently, the bulk tank SCC. Therefore, an early detection of milk with markedly increased SCC is important to prevent its addition to the bulk tank milk. Quarter foremilk sampling before milking for monitoring milk quality and the detection of mastitis, using California Mastitis Test (CMT) or by exact determination of SCC, is well established. However, the estimation of quarter SCC based on foremilk measurements is critical and it has to be taken into account that different milk fractions of a quarter can show different SCC. It was previously shown that the SCC

*For correspondence; e-mail: Rupert.Bruckmaier@physio.unibe.ch of cisternal milk is higher than in the first $25 \%$ of alveolar milk in cows with $<100 \times 10^{3}$ cells $/ \mathrm{ml}$ in whole udder milk (Ontsouka et al. 2003) and the SCC increased in later milk fractions until the end of milking (Vangroenweghe et al. 2002; Sarikaya et al. 2005). In addition, Sarikaya \& Bruckmaier (2006) distinguished between strict foremilk (taken without udder preparation) and cisternal milk where the SCC decreased with each squirt of milk and was higher than in the alveolar milk fractions. This difference between foremilk and alveolar milk was more distinctive at increased total quarter SCC $\left(>100 \times 10^{3}\right.$ cells $\left./ \mathrm{ml}\right)$. Therefore, the definition of the tested fraction is of most importance if the results are used for the prediction of total quarter milk SCC.

To obtain strict foremilk samples without an intermixture with alveolar milk, samples of all quarters must be taken within a lag time of 40-50 s, i.e. before the start of milk ejection (Bruckmaier \& Hilger, 2001). This is often not possible under practical farming conditions. Therefore, 
Table 1. Foremilk and total quarter milk SCC in groups of different foremilk SCC

\begin{tabular}{|c|c|c|c|c|c|}
\hline \multirow{2}{*}{$\begin{array}{l}\text { SCC group } \\
\left(\times 10^{-3} \text { cells } / \mathrm{ml}\right)\end{array}$} & \multirow[b]{2}{*}{$n$} & \multicolumn{2}{|c|}{ Mean SCC values, $\log _{10}$} & \multirow{2}{*}{$\begin{array}{l}\text { Number of } \\
\text { quarters with } \\
\text { numerically } \\
\text { lower SCC } \\
\text { in foremilk, \% }\end{array}$} & \multirow{2}{*}{$\begin{array}{l}\text { Coefficient of } \\
\text { linear regression } \\
(P<0 \cdot 001)\end{array}$} \\
\hline & & Foremilk & Total quarter & & \\
\hline$<20$ & 217 & $4 \cdot 10 \pm 0 \cdot 50^{\mathrm{a}}$ & $4 \cdot 33 \pm 0 \cdot 00^{\mathrm{b}}$ & $70 \cdot 5$ & $1 \cdot 54$ \\
\hline 20 to $<50$ & 412 & $4 \cdot 52 \pm 0 \cdot 39^{a}$ & $4 \cdot 55 \pm 0 \cdot 00^{\mathrm{b}}$ & $46 \cdot 3$ & $1 \cdot 05$ \\
\hline 50 to $<100$ & 300 & $4 \cdot 85 \pm 0 \cdot 61^{\mathrm{a}}$ & $4 \cdot 86 \pm 0 \cdot 65^{a}$ & $42 \cdot 0$ & $1 \cdot 01$ \\
\hline 100 to $<300$ & 373 & $5 \cdot 26 \pm 0 \cdot 47^{a}$ & $5 \cdot 14 \pm 0 \cdot 65^{a}$ & $23 \cdot 3$ & $0 \cdot 75$ \\
\hline 300 to $<500$ & 99 & $5 \cdot 58 \pm 0 \cdot 75^{\mathrm{a}}$ & $5 \cdot 40 \pm 1 \cdot 18^{b}$ & $19 \cdot 2$ & $0 \cdot 67$ \\
\hline$>500$ & 111 & $6 \cdot 07 \pm 1 \cdot 93^{\mathrm{a}}$ & $5 \cdot 77 \pm 1 \cdot 64^{b}$ & $6 \cdot 3$ & $0 \cdot 44$ \\
\hline
\end{tabular}

it is more suitable to remove foremilk samples after milk ejection has commenced. However, the use of foremilk SCC (SCC-F) taken after udder preparation and induction of milk ejection to estimate total quarter SCC (SCC-T) in dairy cows has not been systematically investigated.

The goal of the present study was to test the usefulness of quarter foremilk samples taken after udder stimulation to provide representative data of total quarter SCC.

\section{Material and Methods}

\section{Animals and sampling}

Nineteen dairy cows of different breeds (10 Holstein, 6 Simmental, 3 Swiss Brown) in the middle (week 14-28) of their 1 st to 5 th lactation were used. The cows had a daily milk yield of $27 \cdot 1 \pm 1 \cdot 5 \mathrm{~kg}$ and an average whole udder milk SCC of $(122 \pm 8) \times 10^{3} / \mathrm{ml}$. They were sampled during routine milking twice a day at 5.30 and 15.30 for 10 subsequent days (378 milkings in total). Immediately before the onset of the milking clusters, 10-ml foremilk samples of each quarter were taken after a 1-min udder stimulation by massage of the teats and removing 2-3 jets of milk from each quarter. Milking was performed with a special milking device to collect separate quarter milk. At the end of the milking procedure samples from total milk of each quarter were collected for SCC measurements.

Milk samples were kept at $4{ }^{\circ} \mathrm{C}$ and SCC analyses were performed within $24 \mathrm{~h}$. SCC was measured with the DeLaval cell counter (DCC; DeLaval International, Tumba, Sweden).

\section{Statistical analysis}

Pairs of quarter milk recordings (foremilk $v$. total quarter milk) were analysed by various regression analyses. A random effects linear regression model with maximum likelihood estimates (MLE) and exact confidence intervals was fitted to predict values of $\log (\mathrm{SCC}-\mathrm{T})$. The model included a constant term (intercept), the linear and quadratic form of the predictor $\log (\mathrm{SCC}-\mathrm{F})$, and cow as a random

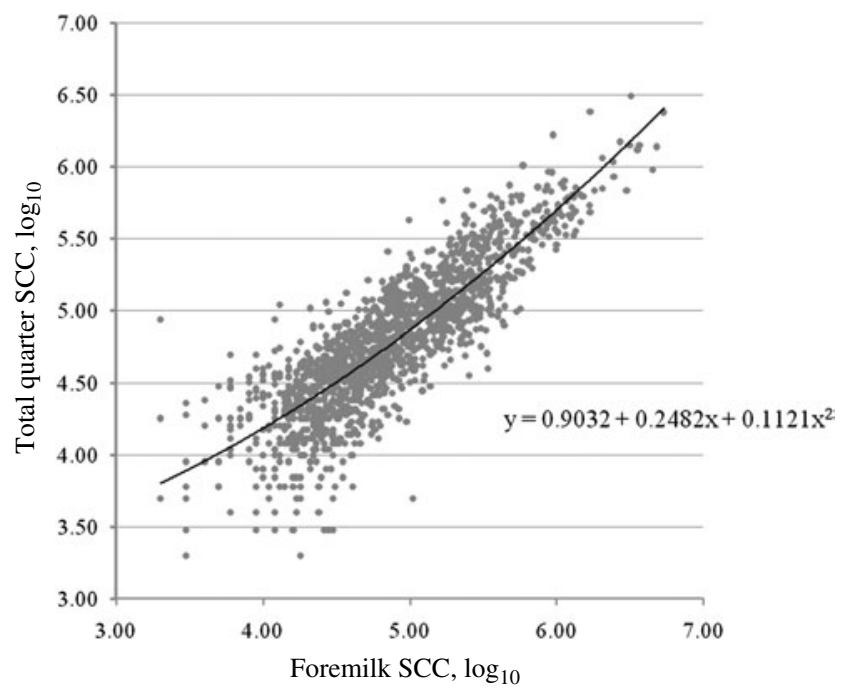

Fig. 1. Polynomial random effects regression of all foremilk $v$. total quarter milk SCC $\left(\log _{10}\right)$ measurements.

effect (STATA 10; function xtreg). The inclusion of cow as a random effect accounted for the repetition of measurements within cow over quarter, milking (morning, afternoon) and time (10 measuring days per cow). Model predictions of $\log (\mathrm{SCC}-\mathrm{T})$ by $\log (\mathrm{SCC}-\mathrm{F})$, therefore, are averages over the possible differences between quarters, milking time, and sampling date. A polynomial regression of all quarter SCC $\left(\log _{10}\right)$ was used to test the relationship between all SCC-T and SCC-F (Fig. 1).

In addition, for a better characterization of the predictability of SCC-T by SCC-F the samples were grouped into six different SCC-F classes $[<20(n=217), 20$ to $<50$ $(n=412), 50$ to $<100(n=300), 100$ to $<300(n=373), 300$ to $<500(n=99)$, and $>500(n=111) \times 10^{3}$ cells $/ \mathrm{ml}$. . (Table 1 , Fig. 2). Data are presented as means with SEM. The association between foremilk and total quarter milk SCC at different SCC classes was determined by simple linear regression (Fig. 3). In all analyses, $P<0.05$ was considered as significant. 


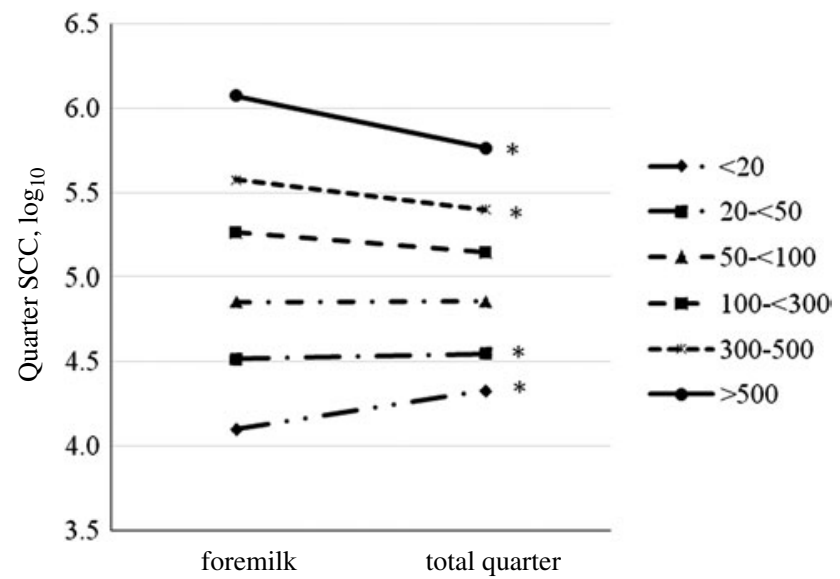

Fig. 2. Mean foremilk and total quarter milk SCC $\left(\log _{10}\right)$ in the six different foremilk SCC groups $[<20(n=217), 20$ to $<50$ $(n=412), 50$ to $<100(n=300), 100$ to $<300(n=373), 300-500$ $(n=99)$ and $>500(n=111) \times 10^{3}$ cells $/ \mathrm{ml}$, respectively]; $*$ indicates a significant difference $(P<0 \cdot 05)$ between foremilk and total quarter SCC within groups.

\section{Results}

A total of 1512 pairs of quarter milk recordings (foremilk $v$. total quarter milk) from 19 dairy cows were analysed. SCC-F ranged from $(5-5400) \times 10^{3}$ cells $/ \mathrm{ml}$, whereas SCC$\mathrm{T}$ ranged from $(2-3100) \times 10^{3}$ cells $/ \mathrm{ml}$, respectively. The polynomial regression of all quarter SCC $\left(\log _{10}\right)$ between all SCC-T and SCC-F showed the equation: $y=0.9032+$ $0 \cdot 2482 \times+0 \cdot 1121 \times{ }^{2}$ (Fig. 1). The percentage of quarters with numerically lower SCC in the foremilk than in the total quarter milk of each group are shown in Table 1. At higher SCC-F levels of $>300 \times 10^{3}$ cells/ml, mean SCC-F were significantly higher than SCC-T (Fig. 2). Only at SCC$\mathrm{F}$ levels of $(50-300) \times 10^{3}$ cells $/ \mathrm{ml}$ did mean foremilk and total quarter SCC not differ considerably. At very low SCC-F levels of $<50 \times 10^{3}$ cells $/ \mathrm{ml}$, SCC were numerically even lower in foremilk than in total quarter milk for most quarters.

Coefficients of linear regression $(P<0 \cdot 001)$ in the groups $<20,20$ to $<50,50$ to $<100,100$ to $<300,300$ to 500 , and $>500 \times 10^{3}$ cells $/ \mathrm{ml}$ were $1.54,1 \cdot 05,1 \cdot 01,0 \cdot 75,0.67$ and $0 \cdot 44$, respectively (Fig. 3 ).

\section{Discussion}

In the present study 1512 SCC measurements of foremilk samples from 19 dairy cows were compared with total quarter SCC. The samples were taken after a 1-min udder stimulation by massage of the teats and removing 2-3 jets of milk from each quarter. Therefore, milk ejection had already commenced and cisternal milk was already mixed with alveolar milk at the time of sampling. This decreases SCC of the cisternal milk because the first alveolar fractions have fewer cells than later milk fractions
(Urech et al. 1999; Waldmann et al. 1999; Ontsouka et al. 2003; Bruckmaier et al. 2004; Tančin et al. 2007). However, taking foremilk samples after udder stimulation was chosen because this is the procedure usually used to collect milk samples for SCC measurement under practical milking conditions and particularly in automatic milking systems where, for technical reasons, no milk samples can be taken before intensive teat cleaning and teat cup attachment. This routine of udder preparation inevitably induces milk ejection before a milk sample can be taken (Dzidic et al. 2004a, b). In conventional milking systems sampling of strict foremilk, i.e. without alveolar milk ejection, is hardly possible in all four quarters because milk sampling induces milk ejection within 40$50 \mathrm{~s}$ of the start of stimulation (Bruckmaier \& Hilger, 2001). Induction of milk ejection via oxytocin is a systemic effect reaching the whole udder; the sampling of the first quarters can induce milk ejection within this short time also in the quarters not yet sampled, and it may well happen that in two or three quarters a sampling of strict foremilk is possible while in the last quarters milk ejection has already occurred (Bruckmaier \& Hilger, 2001; Bruckmaier et al. 2004). However, the purpose of this study was to test the usefulness of foremilk sampling to predict total quarter milk SCC under regular practical conditions.

The results show that total quarter milk SCC cannot be predicted precisely from foremilk SCC measurements. Only when SCC-F was $(50-300) \times 10^{3}$ cells $/ \mathrm{ml}$ did foremilk and total quarter SCC not differ considerably. At higher SCC-F, foremilk after initiation of milk ejection contained more cells than total quarter milk. These results confirm previous investigations (Sarikaya \& Bruckmaier, 2006) where the SCC decreased from strict foremilk to cisternal milk and, furthermore, to the first $400 \mathrm{ml}$ and the rest of the alveolar milk fraction from unstimulated udders in quarters with $>100 \times 10^{3}$ cells $/ \mathrm{ml}$. Most interestingly, in the present study SCC-T was higher than SCC-F when SCC-F was $<50 \times 10^{3}$ cells $/ \mathrm{ml}$. Differently from the results of the present research, Sarikaya \& Bruckmaier (2006) did not see a significant change in groups with $<20$, (20-50), and (50-100) $\times 10^{3}$ cells $/ \mathrm{ml}$ based on 5, 14 and 9 quarter milk samples, respectively. Paape \& Tucker (1966) had already found that the first $20 \mathrm{ml}$ of removed milk had more somatic cells than the second 20-ml fraction and then the SCC increased to strippings and residual milk with an average SCC of $102 \times 10^{3}$ cells $/ \mathrm{ml}$ in the main milk fraction (primary milk removed by machine milking after removal of $180 \mathrm{ml}$ of milk). Low SCC are obviously the reason why Vangroenweghe et al. (2002) found no difference in SCC in strict foremilk, cisternal milk and the alveolar fraction in infection-free quarters with $\mathrm{SCC}<$ $150 \times 10^{3}$ cells $/ \mathrm{ml}$ with an average most likely far below $100 \times 10^{3} \mathrm{cells} / \mathrm{ml}$. In addition, Ontsouka et al. (2003) showed that in cows with a whole udder SCC $<100 \times$ $10^{3}$ cells $/ \mathrm{ml}$ the cisternal milk that was removed before milk ejection did not have a SCC different from the first 
A

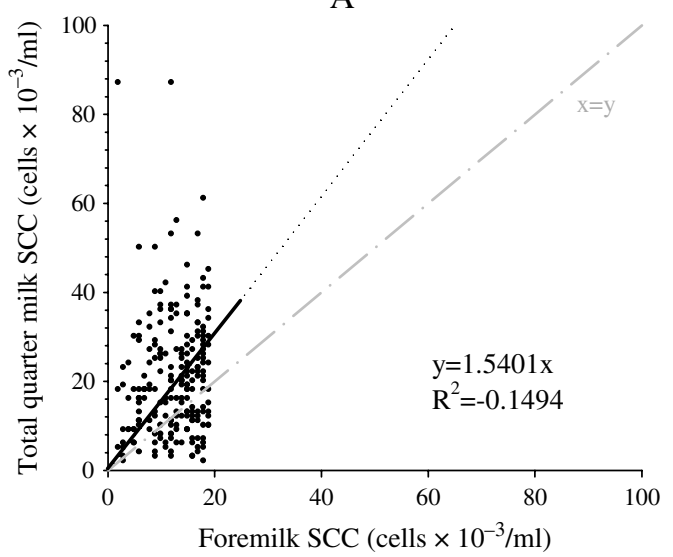

C

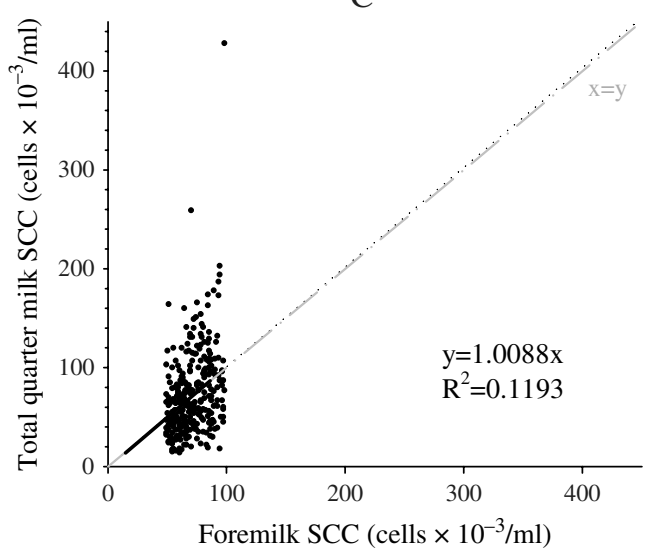

E

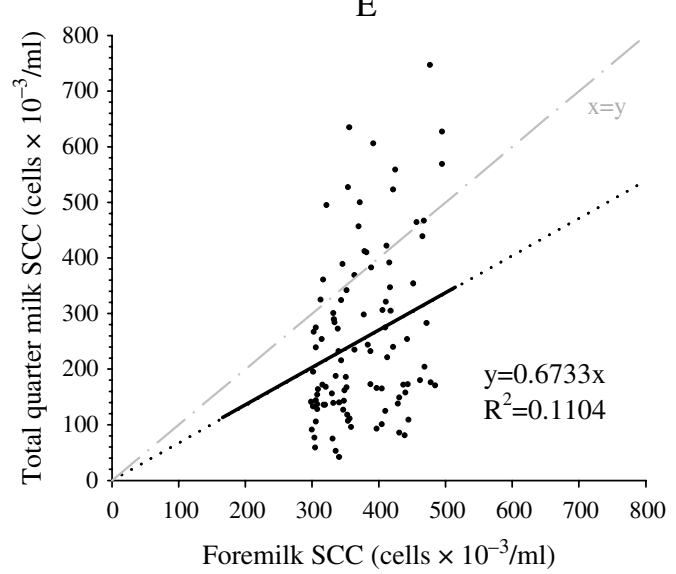

B

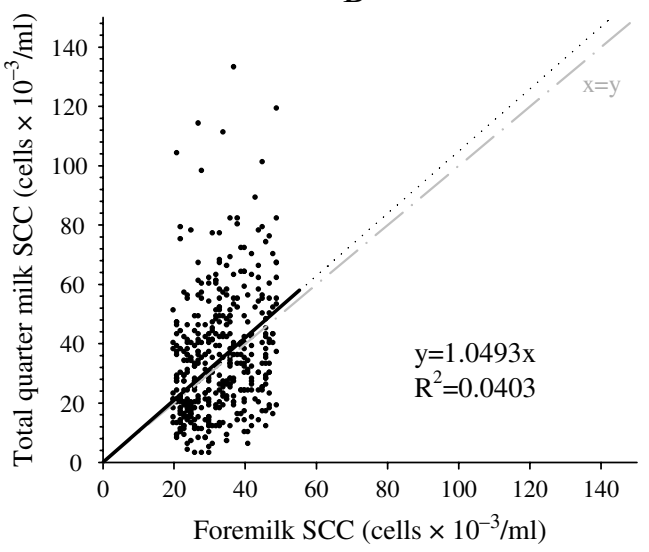

D

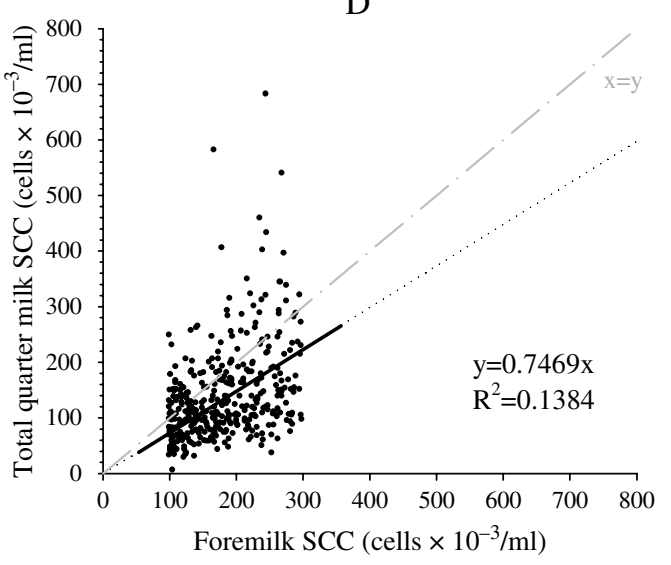

$\mathrm{F}$

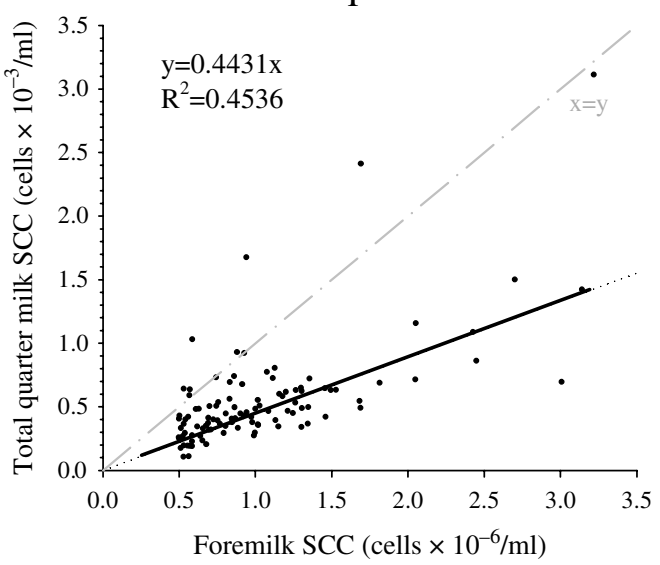

Fig. 3. Linear regressions (black lines; elongations: dotted lines) of total quarter and foremilk SCC grouped into different foremilk SCC: A: $<20 \times 10^{3}$ cells $/ \mathrm{ml}(n=217) ;$ B: 20 to $<50 \times 10^{3}$ cells $/ \mathrm{ml}(n=412) ;$ C: 50 to $<100 \times 10^{3}$ cells $/ \mathrm{ml}(n=300) ; \mathrm{D}: 100$ to $<300 \times 10^{3}$ cells $/ \mathrm{ml}(n=373) ; \mathrm{E}: 300-500 \times 10^{3}$ cells $/ \mathrm{ml}(n=99) ; \mathrm{F}:>500 \times 10^{3}$ cells $/ \mathrm{ml}(n=111)$. A line where $\mathrm{x}=\mathrm{y}$ is indicated in dash - dotted grey.

$25 \%$ and $50 \%$ of the alveolar milk fraction. Only the last $50 \%$ of the alveolar fraction and the residual milk (after high-dosage oxytocin injection) had higher SCC than the cisternal fraction. Furthermore, comparable results were found by Urech et al. (1999). They also described a higher
SCC in foremilk than in bucket milk (main milk fraction) if SCC was elevated $\left(>100 \times 10^{3} / \mathrm{ml}\right)$ during subclinical mastitis. These differences between studies are probably due to a different distribution of SCC levels. If the selection criteria are below a threshold SCC of $(100-200) \times 10^{3} / \mathrm{ml}$ 
the part of quarters below or above $50 \times 10^{3}$ cell $\mathrm{s} / \mathrm{ml}$ have to be taken into account.

The question arises why there is such a difference between foremilk (milk of the cistern) and the alveolar milk. In the presence of chemokines, which are produced during an infection by different cells, there is a high influx of cells in the time between milkings. It is possible that, owing to the large numbers of cells invading the alveoli, a substantial number of these cells leave the alveoli and accumulate in the cisternal milk fraction, leading to a high SCC in the foremilk fraction. Another explanation could be that different mechanisms exist for the transport of cells from blood into milk. While it can be assumed that in the entire secretory parenchyma leucocytes pass by paracellular mechanisms through the tight junctions of the epithelium, it is likely that cells invade the cistern directly in the area of the Fürstenberg's rosette. In this area, a lot of immune cells are found in the tissue, specifically in the epithelial lining (Nickerson \& Pankey, 1983). In addition, it has been shown that in quarters with high cell counts $\left(>100 \times 10^{3} / \mathrm{ml}\right)$ an increased number of cells that express L-selectin and 2-integrin, which they need for diapedesis, are found in this area (Simon et al. 2007). The specific transfer of leucocytes close to the potential entrance port of pathogenic microorganisms would be advantageous in the case of infection. However, in a healthy gland there are almost no chemokines produced and, therefore, the cell influx during the milkings is very low. Then most cells tha invade the mammary gland are in the alveoli and increase the total quarter milk SCC as compared with the foremilk.

The worldwide goal today is to decrease the SCC as much as possible for the best hygienic quality and, most importantly, for the farmers to get the highest price for their milk. The present study showed that foremilk measurements were not suitable to predict the exact value of very low SCC, albeit prediction of the range is well possible. However, under practical farming conditions there is usually no necessity for detection of exact low SCC, only increased SCC values that can reduce the milk quality are of great importance.

In addition, in the present study it was seen that in some cows the differences of foremilk and total quarter milk were extreme, as outliers in the regression analyses illustrate. This variation was not necessarily related to high SCC and shows that single sampling for SCC always has to be interpreted very carefully.

In conclusion, foremilk samples can predict values of quarter milk SCC if the milk contains around (50-300) $\times$ $10^{3} \mathrm{cell} \mathrm{s} / \mathrm{ml}$. At higher SCC values, foremilk samples contain more cells and the difference relative to total quarter milk increases with increasing SCC. At very low SCC levels foremilk contains fewer cells than total quarter milk. Therefore, foremilk samples are useful to detect high quarter milk SCC to recognize infected quarters only when precise cell counts are not required. However, foremilk samples can be misleading if very low cell numbers are to be detected. In addition, it has to be taken into account that individual cows can show dramatic variations in foremilk SCC that are not very well related to total quarter milk SCC.

\section{References}

Bruckmaier RM \& Hilger M 2001 Milk ejection in dairy cows at different degrees of udder filling. Journal of Dairy Research 68 369-376

Bruckmaier RM, Weiss D, Wiedemann M, Schmitz S \& Wendl G 2004 Changes of physicochemical indicators during mastitis and the effects of milk ejection on their sensitivity. Journal of Dairy Research 71 316-321

Dzidic A, Mačuhová J \& Bruckmaier RM 2004a Effects of cleaning duration and water temperature on oxytocin release and milk removal in an automatic milking system. Journal of Dairy Science 874163 4169

Dzidic A, Weiss D \& Bruckmaier RM 2004b Oxytocin release, milk ejection and milking characteristics in a single stall automatic milking system. Livestock Production Science 86 61-68

Nickerson SC \& Pankey J 1983 Cytologic observations of the bovine teat end. American Journal of Veterinary Research 44 1433-1441

Ontsouka CE, Bruckmaier RM \& Blum JW 2003 Fractionized milk composition during removal of colostrum and mature milk. Journal of Dairy Science 86 2005-2011

Paape MJ \& Tucker HA 1966 Somatic cell content variation in fractioncollected milk. Journal of Dairy Science 49 265-267

Sarikaya H \& Bruckmaier RM 2006 Importance of the sampled milk fraction for the prediction of total quarter somatic cell count. Journal of Dairy Science 89 4246-4250

Sarikaya H, Werner-Misof C, Atzkern M \& Bruckmaier RM 2005 Distribution of leucocyte populations, and milk composition, in milk fractions of healthy quarters in dairy cows. Journal of Dairy Research 72 486-492

Simon M, Hluchý S, Horovská L, Antalíková J \& Čuboň J 2007 Immunohistological localization of adhesion molecules (CD62 and CD18) in the mammary gland of dairy cows. Czech Journal of Animal Science 52 88-95

Tančin V, Uhrinčat M, Mačuhová L \& Bruckmaier RM 2007 Effect of pre-stimulation on milk flow pattern and distribution of milk constituents at a quarter level. Czech Journal of Animal Science 52 117-121

Urech E, Puhan Z \& Schällibaum M 1999 Changes in milk protein fraction as affected by subclinical mastitis. Journal of Dairy Science $\mathbf{8 2}$ 2402-2411

Vangroenweghe H, Dosogne H \& Burvenich C 2002 Composition and milk cell characteristics in quarter milk fractions of dairy cows with low cell count. Veterinary Journal 164 254-260

Waldmann A, Ropstad E, Landsverk K, Sørensen K, Sølverød L \& Dahl E 1999 Level and distribution of progesterone in bovine milk in relation to storage in the mammary gland. Animal Reproduction Science $\mathbf{5 6}$ 79-91 